\title{
Prognostic implications of Anemia in patients with Acute Heart Failure in emergency departments. ANEM-AHF Study.
}

\author{
Angeles Fernández-Rodriguez ${ }^{1}$, Belén Prieto-García ${ }^{1}$, Joaquín Vázquez-Álvarez ${ }^{1}$, Javier \\ $\mathrm{Jacob}^{2}$, Victor Gil ${ }^{3}$, Òscar Miró ${ }^{3}$, Pere Llorens ${ }^{4}$, Francisco Javier Martín-Sánchez ${ }^{5}$, Aitor \\ Alquezar $^{6}$, Pilar López-Díez ${ }^{7}$, Esther Rodríguez-Adrada ${ }^{8}$, Rodolfo Romero-Pareja ${ }^{9}$, and \\ Pablo Herrero-Puente ${ }^{1}$
}

${ }^{1}$ Hospital Universitario Central de Asturias

${ }^{2}$ Hospital Universitari de Bellvitge

${ }^{3}$ Hospital Clinic de Barcelona

${ }^{4}$ Alicante General University Hospital

${ }^{5}$ Hospital Clínico San Carlos

${ }^{6}$ Hospital de la Santa Creu i Sant Pau

${ }^{7}$ Hospital Universitario de Burgos

${ }^{8}$ Hospital Universitario Rey Juan Carlos

${ }^{9}$ Hospital Universitario de Getafe

July 13, 2020

\begin{abstract}
INTRODUCTION: The anemia leads to a worse prognosis in patients with heart failure(HF). There are few data on the impact of anemia on mortality in patients with acute heart failiure(AHF), and the studies available are mainly retrospective and include hospitalized patients. OBJECTIVE. Evaluate the role of anemia in 30-days and one-year mortality in patients with AHF attended in hospital emergency departments(HEDs). METHODS. Multicenter, observational study of prospective cohorts of patients with AHF. Study variables: anemia(hemoglobin $<12 \mathrm{~g} / \mathrm{dL}$ in women and $<13 \mathrm{~g} / \mathrm{dL}$ in men), 30-days-mortality and at one year, risk factors, comorbidity, functional impairment, basal functional grade for dyspnea, chronic and acute treatment, clinical and analytical data of the episode and patient destination. Statistical analysis: bivariate analysis and survival analyses using Cox regression. RESULTS. A total of 13,454 patients were included, 7662(56.9\%) of whom had anemia. Those with anemia were older, had more comorbidity, a worse functional status and New York Heart Association class, greater renal function impairment and more hyponatremia. The mortality was higher in patients with anemia at 30-days and one-year: $7.5 \%$ vs. $10.7 \%(\mathrm{p}<0.001)$ and $21.2 \%$ vs. $31.4 \%(\mathrm{p}<0.001)$, respectively. The crude and adjusted hazard ratios of anemia for 30-days-mortality were: 1.46 (confidence interval[CI]95\% 1.30-1.64); $<0.001$ and $1.20(\mathrm{CI} 95 \% 1.05-1.38) ; \mathrm{p}=0.009$, respectively, and 1.57 (CI95\% 1.47-1.68) and 1.30(CI95\% 1.20-1.40) for one-year-mortality. The weight of anemia on mortality was different in each follow-up period. CONCLUSIONS. Anemia is an independent predictor of 30-days-mortality and one year in patients with AHF attended in HEDs. It is important to study the etiology of AHF since adequate treatment would reduce mortality.
\end{abstract}

\section{INTRODUCTION}

Acute heart failure (AHF) is the final consequence of a large number of cardiovascular diseases and is one of the most important health care problems in developed countries. The prevalence of AHF is increasing with the aging of the population ${ }^{1}$. This disease causes relevant mordibity and mortality and is among the 
main causes of hospitalization, hospital mortality and health care costs in Spain ${ }^{2,3,4,5}$, with most hospital admissions being made through hospital emergency departments (HEDs) ${ }^{6,7,8,9}$.

Although the role of anemia as a triggering factor of cardiac decompensation is well known ${ }^{10}$, in the last years the study of anemia in patients with heart failure (HF) has become the focus of increasing interest due to its elevated prevalence and prognostic implications. HF has been described as being associated with greater hospitalization and with an increase in mortality in patients with a reduced and preserved ejection fraction ${ }^{11}$. The prevalence of HF varies widely in the different studies available, ranging from 4 to $55 \%$, with one third of the patients presenting decompensated $\mathrm{HF}^{12,13}$. This variability can be explained by the different study populations selected and by the absence of consensus in relation to the definition of anemia in the different studies ${ }^{14}$, although when using the criteria of the World Health Organization (WHO) (hemoglobin $[\mathrm{Hb}]<12 \mathrm{~g} / \mathrm{dl}$ in women and $<13 \mathrm{~g} / \mathrm{dl}$ in men), the prevalence is $30 \%$ in stable patients and $50 \%$ in decompensated hospitalized patients ${ }^{15}$.

The cause of anemia in patients with HF is probably multifactorial. Different mechanisms have been described $^{16}$ : reduction in intestinal iron absorption, increase in cytosines, activation of the renin-angiotensinaldosterone system, renal dysfunction due to vasoconstriction and renal ischemia and loss of erythropoietin and transferrin by the coexistence of proteinuria and hematic losses related to antiaggregant or anticoagulant treatments.

Multiple observational studies have found that the presence of anemia conditions a worse prognosis in patients with $\mathrm{HF}^{17}$, in terms of mortality and readmission due to decompensation of HF. Data on the impact of anemia on mortality in patients with AHF are scarce, and the studies available are retrospective and usually include patients who are hospitalized in conventional hospital wards. In a recent study including 756 patients admitted for $\mathrm{AHF}$, it was observed that $\mathrm{Hb}$ values $<10 \mathrm{~g} / \mathrm{dL}$ were significantly related to a greater mortality at 3 years, greater readmission at 30 days and longer hospital stay ${ }^{18}$.

It has been reported that the use of iron and erythropoietin may be beneficial in these patients. Silverberg and $\mathrm{col}^{19}$ demonstrated that this treatment improved the ventricular ejection fraction and functional capacity in a group of refractory HF patients. The beneficial effect of the correction of anemia in this group of patients was translated into a better quality of life, functional capacity and lower rate of readmissions.

It is still not clear whether the association between anemia and the outcomes of patients with AHF is causal or anemia is a marker of risk. The favorable results of studies on the treatment of anemia together with the harmful hemodynamic effects and the possibilty that it favors myocardial ischemia support a cause-effect relationship. Therefore, the main aim of this study was to evaluate the effect of anemia on short-term mortality (30 days) and at one year in patients with AHF and determine the implication of anemia in progressive mortality from patient inclusion until one year of follow-up.

\section{MATERIAL AND METHODS}

The Anemia in patients with AHF study (ANEM-AHF) is a secondary analysis of the Epidemiology of Acute Heart Failure in Emergency Departments (EAHFE) registry. The EAHFE registry was initiated in 2007 and each 2-3 years consecutively includes all the patients diagnosed with AHF attended in HEDs in the participating centers during a 2-3 month period. To date, 5 inclusion phases have been carried out (2007, 2009, 2011, 2014 and 2016) by 41 Spanish HEDs which have included a total of 13,791 patients. The methodology has been described in previous publications ${ }^{20,21}$.

The EAHFE registry is a multicenter, multipurpose, non interventional, observational study with prospective follow-up of the cohorts of patients diagnosed with AHF in HEDs. The diagnosis of AHF was made according to the criteria of the guidelines of the European Society of Cardiology (ESC) prevailing at patient recruitment ${ }^{22}$, together with the Framingham criteria, and natriuretic peptides and/or echocardiography, in cases in which these were available. Prior to the inclusion period the physicians in the participating HEDs received specific training by the principal investigator of each center on the registry and the inclusion and exclusion criteria. Later, the principal investigator of each HED reviewed and revised the diagnosis of each 
patient included and was responsible for the final diagnosis and definitive inclusion of the patient in the study. The only exclusion criterium was having a principal diagnosis of acute coronary syndrome with ST elevation with later development of AHF.

Some of the variables were collected retrospectively with information from the clinical history as well as the anamnesis made during study in the HED. The variables related to the acute episode were collected prospectively as well as those of the follow-up which was made by telephone and consultation of the clinical histories in the hospital and primary care offices between 30 and 60 days after inclusion and at one year.

\section{Commitment to confidentiality and ethical consideracions}

The EAHFE registry was approved by the regional Ethics Committee of Clinical Investigation of the Principality of Asturias. All the patients provided signed informed consent for participation in the study and posterior follow-up. The data were encoded and managed with complete confidentiality and were only accessible to the investigators of each of the participating centers. The ANEM-AHF study was performed according to the principles of the Declaration of Helsinki for biomedical investigation.

Variables.

The endpoint variables were all-cause mortality at 30 days and one year after inclusion, with monthly intermediate analyses and reconsultation to the HED within 30 days for a new episode of AHF.

The following data were collected from all the patients: age and sex, data of the triage in the HED (systolic and diastolic blood pressure, heart rate and respiratory frequency), previous history of cardiovascular and non cardiovascular disease, grade of functional dependence measured by the Barthel index and functional grade for dyspnea according to the scale of the New York Heart Association (NYHA), echocardiography and type of dysfunction, clinical data of the acute episode, chronic treatment of the patient and treatment during care in the HED, complementary analytical tests including complete blood count, glucose, urea, creatinine, sodium, potassium, troponins and natriuretic peptides. The estimated glomerular filtration rate (eGFR) was calculated using the Chronic Kidney Disease Epidemiology Collaboration (CKD-EPI) formula ${ }^{23}$, and data from the electrocardiogram, patient admission and discharge, stay in the observation unit and the date of definitive discharge were also collected.

\section{Laboratory tests}

Sample collection and processing for hematological parameters was carried out in EDTA-Ke tubes for the hemogram and according to the criteria of the attending physician also in a tube with citrate as an anticoagulant. The samples were immediately sent to the rapid response laboratory of the participating centers where they were processed following the protocol of each center. Anemia was defined according to the WHO criteria, with $\mathrm{Hb}$ values $<13 \mathrm{~g} / \mathrm{dL}$ for men and $<12 \mathrm{~g} / \mathrm{dL}$ for women ${ }^{24}$.

The patients were divided into two gropus based on whether they had or did not have anemia using the previously mentioned criteria, with the results of the $\mathrm{Hb}$ values of the analyses carried out during care in the HED.

\section{Statistical analysis}

Data analysis was performed in several phases. Univariate analysis: the qualitative variables are described as number and percentage and the quantative data are expressed as mean, standard deviation (SD) and median and 25th and 75th percentiles. Bivariate analysis: Comparison were made using the Chi-square or Fisher exact test for qualitative variables and the Student's t test for quantitative variables. For variables with a non normal distribution the corresponding non parametric tests were used. Survival analysis was performed by the Cox proportional hazards method calculating rates of risk using the backward step method applying the likelihood ratio to determine the significance of the model.

An exploratory model was previously used to preselect the variables based on the results of the Cox regression analysis with a single independent variable, and those with a $\mathrm{p}$ value $<0.05$ were introduced into multivariate 
analysis. The dependent variable was mortality at 30 days and one year after the index episode and stepwise regression of the variables selected was made generating 6 different partial scaled models until a global model was obtained. The effect of anemia on monthly mortality from the day of inclusion until one year of follow-up was analyzed, only including the patients who were alive at each of the time periods. The statisical analyses were performed using SPSS 24.0.

\section{RESULTS}

Baseline characteristics of the patients and comparison between the group with anemia and the control group.

A total of 13,791 patients were included, 13,454 of whom had valid $\mathrm{Hb}$ values and were finally included in the analysis (Figure 1). The Hb values were [(median (p25-p75)] $12 \mathrm{~g} / \mathrm{dL}(10.6-13.3)$, and 7,662 (56.9\%) patients had anemia. The frequency of anemia increased with age: being $46.5 \%$ in subjects under 65 years of age, $54 \%$ between 65 and 75 , and $58.8 \%$ in individuals over the age of 75 ( $\mathrm{p}$ of the linear trend $<0.001$ ).

Table 1 shows the baseline charactistics of the population and comparison of the two groups. The mean age of the patients was 80 (10) years, and $55.5 \%$ were women. The group with anemia was older [80.6(9.5) vs. $79.2(9.5), \mathrm{p}<0.001)$, with a lower percentage of women $(52.5 \%$ vs. $59.6 \%, \mathrm{p}<0.001)$ and a greater frequency of risk factors and cardiovascular comorbidity, except for atrial fibrillation $(\mathrm{p}=0.33)$. The patients with anemia had a higher percentage of functional class for dyspnea NYHA III-IV (26.7 vs. 22.2, p < 0.001) and a Barthel index $<60$ points $(20.7$ vs. 16.3, p $<0.001)$. Chronic treatment included more loop and potassium sparing diuretics, beta-blockers, antiaggregants, digoxin, nitrates and statins. In relation to the complementary tests, the group with anemia showed greater renal function impairment, with a percentage of patients with a greater eGFR $<60 \mathrm{ml} / \mathrm{min}(70.9$ vs. $53.8, \mathrm{p}<0.001)$ and more hyponatremia (20.3 vs. $16.1, \mathrm{p}<0.001)$. Among the biomarkers, patients with anemia had higher N-terminal brain natriuretic peptid $(\mathrm{NTproBNP})$ values [8472 $(13676) \mathrm{pg} / \mathrm{mL}$ ] than patients without anemia [6812 (13093), $\mathrm{p}<0.001]$ and had a higher percentage of positive troponin values (58.4 vs. 51.1, $\mathrm{p}<0.001)$.

Anemia as a prognostic factor of mortality

Mortality was greater in patients with anemia: $7.5 \%$ in individuals without anemia vs. $10.7 \%$ with anemia $(\mathrm{p}<0.001)$, and $21.2 \%$ vs. $31.4 \%(\mathrm{p}<0.001)$ at 30 days and at one year, respectively. When patients were classified based on $\mathrm{Hb}$ values, the mortality at 30 days and at one year was: mortality at 30 days $10.7 \%$ with $\mathrm{Hb}<7 \mathrm{~g} / \mathrm{dL}, 14.3 \%$ with $\mathrm{Hb}$ between 7 and $9 \mathrm{~g} / \mathrm{dL}, 10.4 \%$ with $\mathrm{Hb}$ between 9 and $11 \mathrm{~g} / \mathrm{dL}, 9.5 \%$ with $\mathrm{Hb}$ between 11 and $13 \mathrm{~g} / \mathrm{dL}$ and $7.1 \%$ whit $\mathrm{Hb}>13 \mathrm{~g} / \mathrm{dL}$, p-value for trend $<0.001$; mortality at one year $30 \%$ with $\mathrm{Hb}<7 \mathrm{~g} / \mathrm{dL}, 36.8 \%$ with $\mathrm{Hb}$ between 7 and $9 \mathrm{~g} / \mathrm{dL}, 31.9 \%$ with $\mathrm{Hb}$ between 9 and $11 \mathrm{~g} / \mathrm{dL}, 27.6 \%$ with $\mathrm{Hb}$ between 11 and $13 \mathrm{~g} / \mathrm{dL}$ and $20 \%$ with $\mathrm{Hb}>13 \mathrm{~g} / \mathrm{dL}$, p-value for trend $<0.001$. Figure 2 shows the crude hazard ratios $(95 \%$ confidence interval $[95 \% \mathrm{CI}]$ ) for each range of Hb values of mortality at 30 days and at one year.

Patients with anemia had a greater crude in-hospital [HR(95CI\%): 1.40(1.23-1.60), $\mathrm{p}<0.001]$, and 30-day [HR(95CI\%): 1.46(1.30-1.64), $\mathrm{p}<0.001]$ and one-year [HR(95CI\%): 1.57(1.47-1.68), $\mathrm{p}<0.001$ ] mortality (Figure 2). In the multivariate analysis (figures 3 and 4), the effect of anemia on mortality remained significant after having controlled for confounding factors in the different partial models to the global model HR(CI95\%): $1.20(1.05-1.38), \mathrm{p}=0.009$ for 30-day mortality ant 1.30(1.20-1.140), $\mathrm{p}<0.001$ for one-year mortality.

The most important change in the HR (CI95\%) in relation to the influence of anemia on mortality was observed when: in the case of mortality at 30 days, age and variables of comorbidity were introduced into the model, leading to a reduction to $12.3 \%$ in the HR; and in relation to mortality at one year, the change in the crude HR and that adjusted for age, sex and comorbidity was $15.2 \%$. There were no important variations in the other partial models (Figures 3 and 4 ).

Data on the type of dysfunction were only available in 5427 patients (40.3\%), and of these, 2936 (54\%) had a reduced ejection fraction. We performed a stratified analysis of mortality at 30 days and one year between these two groups. In the case of patients with heart failure and a reduced ejection fraction, the crude 
HR (CI95\%) was 1.43 (1.08-1.89), $\mathrm{p}=0.01$ for 30-day mortality and 1.60 (1.37-1.89), $\mathrm{p}<0.001$ for one-year mortality, and the adjusted values were 1.28 (0.96-1.71), $\mathrm{p}=0.09$ and $1.37(1.16-1.62), \mathrm{p}<0.001$, respectively. In the case of heart failure with a preserved ejection fraction, the crude HR values were $1.52(1.08-2.14)$, $\mathrm{p}=0.02$ mortality at 30 days and $1.51(1.25-1.82), \mathrm{p}<0.001$ for mortality at one year. The adjusted values were 1.48 (1.04-2.11), $\mathrm{p}=0.03$ and 1.35 (1.11-1.64), $\mathrm{p}=0.003$, respectively.

Effect of anemia on mortality in the individual time periods studied.

In the analysis of risk for the individual time periods (Figure 5), the effect on mortality was lost in the intermediate follow-ups but gained increasing importance after the eighth month of follow-up, being greater in patients who were alive in the last month of follow-up.

\section{DISCUSSION.}

Anemia is an important comorbidity in patients with AHF, however, most studies on the influence of early and long-term mortality included patients admitted to different hospitalization units ${ }^{16,25}$. The EAHFE registry includes patients with AHF attended in HEDs, including patients admitted as well as those discharged after their first episode or managed in alternative hospitalization units (Observation Units or Short-stay Units), which are not usually represented in other studies. The ANEM-AHF study was also aimed at determining the influence of anemia as a prognostic factor of short- and long-term mortality in patients with AHF attended in HEDs and to determine the influence in relation to the rest of the variables which act as confounding factors, an aspect which, up to now, has not been reported in the literature. On the other hand, it also measured the potential increase in individual risk at different time points during follow-up.

The principal findings of the ANEM-AHF were: 1) the frequency of anemia in patients attended in HEDs is higher than what has been reported in the literature in hospitalized populations and significantly increases with age; 2) anemia is a prognostic factor of early (30 days after inclusion) and long-term (at one year) mortality, and this prognostic capacity is independent of the differences between the groups with and without anemia; 3) age, sex and comorbidity are confounding factors which produce a clinically relavant effect on the relation between anemia and mortality at 30 days and at one year, and the remaining parameters (baseline NYHA, previous treatment, clinical and analytical and electrocardiographic data of the acute episode, emergency treatment and hospital admission) have a lesser impact; and 4) the effect of anemia on mortality is much greater in the long term than in intermediate follow-ups.

The prevalence of anemia in our cohort was $56.9 \%$, being higher than that of other studies which ranged from 30 to $50 \%$, and increased with age ${ }^{9}$. This greater frequency is probably influenced by age since its coincides with the findings of the study by Formiga ${ }^{26}$ who analyzed the effect of anemia in 155 patients with AHF over 90 years of age and found a prevalence of $60 \%$, which is very similar to that of our patients.

Patients with anemia differ from those without this comorbidity, being a common aspect in different studies $^{9,16,23}$ : these patients are older, have more comorbidities, a worse basal status, and are more often admitted for an acute episode. Anemia was more frequent among males than controls, contrary to what has been described in the literature in which women predominate among patients with anemia or there are no differences between sexes ${ }^{9,16}$. Taking into account the data of our large, country-wide study, we consider that these findings are representative of the real population with anemia and AHF.

Anemia is correlated with a higher early and long-term mortality. The relationship between $\mathrm{Hb}$ values and mortality was not linear. Patients with lower Hb values $(7 \mathrm{~g} / \mathrm{dL})$ presented a lower mortality than those with intermediate values. This aspect differs from that seen in patients with chronic heart failure ${ }^{27}$ and favors the results of older studies which attempted to demonstrate that the relation between $\mathrm{Hb}$ values and mortality followed a $\mathrm{J} \operatorname{curve}^{28}$. This result may have been due to these patients with such low Hb values having received treatment for anemia early on, whether by transfusion or with intravenous iron, conditioning the prognosis, especially in the short term.

The principal finding of our study is the relationsip between anemia and both short- (30 days) and longterm mortality (at one year), which remained independent of all the confounding factors composed of 56 
variables including comorbidity, both basal functional status and dyspnea, chronic treatment of the patient, data of the acute episode, analytical results, treatment administered in the HED and hospital admission or stay in an observation unit. After controlling for these factors, patients with anemia presented an excess of mortality of $30 \%$ at 30 days and $30 \%$ at one year. The factors which had the greatest impact on this relation and produced a significant change in the HRs were age, sex and comorbidity. Previous studies have analyzed long-term mortality and other prognostic factors such as readmission within 30 days. Our results of mortality at one year are concordant with previous studies which have also observed that the presence of low $\mathrm{Hb}$ values is an independent marker of mortality at 3 years, although the survival curves separate from the beginning and become parallel after one year of follow-up ${ }^{16}$. This may have implications in the follow-up of patients with AHF once the acute phase has been overcome. On one hand, it would be important to establish the etiological diagnosis of anemia to administer treatments targeted at reestablishing Hb values, especially in patients with values for which transfusion is not indicated. Based on the findings of the Ferinject assessment in patients with IRon deficiency and chronic Heart Failure (FAIR-HF) study ${ }^{29,30}$, the use of is recommended in patients with iron deficiency who do or do not have anemia. Indeed, the clinical guidelines of the $\mathrm{ESC}^{22}$ recommend that this comorbidity should be monitored during the follow-up of these patients. In the analysis of the impact of anemia on mortality at different one month time periods between 30 days and one year, we observed that anemia is independently correlated with early mortality and mortality after 300 days of follow-up, at which time mortality exponentially increases, making close follow-up of these patients necessary in order to control the $\mathrm{Hb}$ values.

To our knowledge no study has analyzed the effect of anemia on short-term mortality or has measured the risk of individual mortality at the different time periods analyzed until the end of follow-up. In the case of mortality at 30 days, anemia is an independent marker of risk. This highlights the need for studies on the etiology of anemia at the time of diagnosis in order to implement the most adequate treatment, since anemia is a comorbidity, which, on many occasions, in easily treatable considering that the main causes are usually nutritional deficits, mainly of iron or situations of chronic inflammation which are often found in patients with HF.

\section{LIMITATIONS.}

This study has several limitations which should not condition the validity of the results. On one hand, patients with a previous diagnosis of anemia were not recruited and this was established based on the $\mathrm{Hb}$ value during care in the HED. On the other hand, it is a study on real-life management of patients with AHF, without intervention and in which the physicians attending the patients did not receive instructions regarding their management. Another limitation is that this was not the principal objective of the study, although it had a multipurpose design. The last limitation is that patient inclusion was based on clinical criteria and patients belonging to a single country, although the participating hospitals were from all around Spain.

Nonetheless, despite these limitations we believe that the results of the ANEM-AHF study including a large registry of patients with AHF attended in HEDs are perfectly valid and can be extrapolated to other similar populations.

\section{REFERENCES}

1. Anguita-Sánchez M, Crespo-Leiro MG, De Teresa-Galván E, Jimenez-Navarro M, Alonso-Pulpón L, Muñiz-García J, et al. Prevalencia de la insuficiencia cardiaca en la población general española mayor de 45 años. Estudio PRICE. Rev Esp Cardiol 2008;61:1041-9.

2. Rodríguez-Artalejo F, Banegas-Banegas JR, Guallar-Castillón P. Epidemiología de la insuficiencia cardiaca. Rev Esp Cardiol 2004;57:163-70.

3. Sayago-Silva I, García-López F, Segovia-Cubero J. Epidemiología de la insuficiencia cardiaca en España en los últimos 20 años. Rev EspCardiol2013;66:649-56.

4. Kirkwood FA, Uddin N, Patterson JH. Clinical predictors of in-hospital mortality in acutely decompensated heart failure-piecing together the outcome puzzle. Congest Heart Fail 2008;14:127-134. 
5. Fonarow GC. Epidemiology and risk stratification in acute heart failure. Am Heart J 2008;155:200-7.

6. Moreno-Millán E, García-Torrecillas JM, Lea-Pereira MC. Diferencias de gestión entre los ingresos urgentes y los programados en función de los grupos relacionados de diagnóstico y la edad de los pacientes. Emergencias 2007;19:122-8.

7. Llorens P, Miró O, Martín-Sánchez FJ, Herrero-Puente P, Jacob-Rodríguez J, Gil V, et al. Manejo de la insuficiencia cardiaca aguda en los servicios de urgencias y unidades adscritas. Documento de consenso del Grupo de Insuficiencia Cardiaca Aguda de la Sociedad Española de Medicina de Urgencias y Emergencias. Emergencias2011;23:119-39.

8. Llorens P. Necesidad de evaluar el riesgo de los pacientes con insuficiencia cardiaca aguda en los Servicios de Urgencias mas allá del juicio clínico. Emergencias 2018;30:75-6.

9. Martín-Sanchez FJ, Rodriguez-Adrada E, Vidan MT, Diez-Villanueva P, Llopis García G, Gonzalez del Castillo J, et al. Impacto de las variables geriátricas en la mortalidad a 30 días de los ancianos atendidos por Insuficiencia Cardiaca Aguda. Emergencias 2018;30:149-55.

10. Aguirre-Tejedo A, Miró O. Prevalencia de factores precipitantes de insuficiencia cardiaca aguda y su impacto pronóstico: una revisión sistemática. Emergencias 2016;28:185-93.

11. Anand IS, Gupta P. Anemia and iron deficiency in Heart Failure. Current concepts and Emerging Therapies. Circulation2018;138:80-98.

12. Mentz RJ, Greene SJ, Ambrosy AP, Vaduganathan M, Subacius HP, Chioncel O, et al. Clinical profile and prognostic value of anemia at the time of admisión and discharge among patients hospitalized for heart failure with reduced ejection fraction: findings from the EVEREST trial. CircHeartFail2014;7:4018.

13. O'Meara E, Murphy C, McMurray JJ. Anemia and heartfailure. CurrHeartFailRep2004;1:176-82.

14. Komajda M Prevalence of anemia in patients with chronic heart failure and their clinical characteristics. J CardFail. 2004;10 Suppl1:1-4

15. O'Meara E, Clayton T, McEntergat MB, McMurray JJ, Lang CC, Roger SD, et al. Clinicalcorrelates and consequences of anemia in a broad spectrum of patients with heart failure: results of the Candesartan in Heart Failure: Assessment of Reduction in Mortality and Morbidity (CHARM) Program. Circulation2006;113:986-94.

16. Lupon J Urrutia A, Gonzalez B, Herreros J, Altimir S, Coll R, et al. Significado pronóstico de los valores de hemoglobina en pacientes con Insuficiencia Cardiaca. RevEspCardiol 2005;58:48-53

17. Kosiborod M, Curtis JP, Wang Y, Smith GL, Masoudi FA, Foody JM et al. Anemia and outcomes in patients with heart failure. A study from the National Heart Care Project. ArchInternMed. 2005; $165: 2237-44$

18. Halawa A, Burton MC, Maniaci MJ, Shapiro BP, Yip DS, Hodge DO, et al. Association of anemia without comes of acute heart failure. Southerm Medical Journal 2018;111:103-8.

19. Silverberg DS, Wexler D, Sheps D, Blum M, Keren G, Baruch R, et al. The effect of correction of mild anaemia in severe, resistant congestive heart failure using subcutaneous erythropoietin and intravenousiron: a randomised controlled study. J Am CollCardiol. 2001;37:1775-80

20. Miró O, Llorens P, Escalada X, Herrero P, Jacob J, Gil V, et al. Atención prehospitalaria a los pacientes con insuficiencia cardiaca aguda en España: Estudio SEMICA. Emergencias 2017;29:223-30.

21. Miró O, Rossello X, Gil V, Marín-Sánchez FJ, Llorens P, Herrero-Puente P, et al. Predicting 30-days mortality for patients with Acute Heart Failure in Emergency Department: A Cohort Study. Ann InternMed2017;167:698-705.

22. Ponikowski P, Voors AA, Anker SD, Bueno H, Cleland JGF, Coats AJS, et al. Guias ESC 2016 sobre el diagnostico y tratamiento de la insuficiencia cardiaca aguda y crónica. RevEspCardiol2016;69:1167.e1e85.

23. Levey AS, Stevens LA, Schmid CH, Zhang YL, Castro AF 3rd, Feldman HI, et al. ; CKD-EPI (Chronic Kidney Disease Epidemiology Collaboration). A new equation to estimate glomerular filtrationrate. Ann InternMed2009;150:604-12.

24. Organización Mundial de la Salud. Concentraciones de hemoglobina para diagnosticar la anemia y evaluar su gravedad. Ginebra, Organización Mundial de la Salud, 2011 (WHO/NMH/NHD/MNM/11.1) 
(http://www.who.int/vmnis/indicators/haemoglobin_es.pdf, consultado el 25 de febrero de 2019).

25. Al-Jarallah M, Rajan R, Al-Zakwani I, Dashti R, Bulbanat B, Sulaiman K, et al. Incidence and impact of cardiorenal anaemia síndrome on all-cause mortality in acute heart failure patients stratified by left ventricular ejection fraction in theMiddle East. ESC HeartFailure2019;6:103-10.

26. Formiga F, Chivite D, Ariza-Solé A, Corbella X. Mild anemia and mortality in very old adults hospitalized for acute heart failure. J Am GeriatricSoc2018;66:2432-4.

27. Sharma R, Francis DP, Pitt B, Poole-Wilson PA, Coats AJ, Anker SD. Haemoglobin predicts survival in patients with chronic heart failure: substudy of the ELITE II trial. EurHeart J 2004;25:1021-28.

28. Gagnon DR, Zhang TJ, Brand FN, Kannel WB. Hematocrit and the risk of cardiovascular disease: the Framingham study: a 34-year follow up. Am Heart J 1994;127:674-82.

29. Anker SD, Comin Colet J, Filippatos G, Willenheimer R, Dickstein K, DrexlerH, et al. Ferric carboxymaltose in patient with heart failure and iron deficiency. N Engl J Med. 2009;361:2436-48.

30. Filippatos G, Farmakis D, Colet JC, Dickstein K, Luscher TF, Willenheimer R,et al. Intravenous ferric carboxymaltose in iron-deficient in chronic heart failure patients with and without anaemia: a subanalysis of the FAIR-HF trial. Eur J Heart Fail. 2013;15:1267-76.

Table 1. Baseline characteristics of the study population and comparison of the characteristics of the patients based on whether they had anemia or not.

\begin{tabular}{|c|c|c|c|c|c|}
\hline & $\begin{array}{l}\text { Total } \\
N=13454\end{array}$ & Missing values & $\begin{array}{l}\text { ANEMIA } \\
\text { GROUP } \\
\mathrm{N}=7662\end{array}$ & $\begin{array}{l}\text { CONTROL } \\
\text { GROUP } \\
\mathrm{N}=5792\end{array}$ & p-value \\
\hline \multicolumn{6}{|c|}{$\begin{array}{l}\text { SociodemographiSociodemographiSociodemographiSociodemographiSociodemographiSociodemographic } \\
\text { variables }\end{array}$} \\
\hline $\begin{array}{l}\text { Age (años) } \\
{[\text { mean (SD)] }}\end{array}$ & $80(10)$ & $0(0 \%)$ & $80.6(9.5)$ & $79.2(9.5)$ & $<0.001$ \\
\hline $\begin{array}{l}\text { Female sex }[\mathrm{n} \\
(\%)]\end{array}$ & $7473(55.5)$ & $0(0 \%)$ & $4023(52.5)$ & $3450(59.6)$ & $<0.001$ \\
\hline $\begin{array}{l}\text { Variables of } \\
\text { comorbidity }\end{array}$ & $\begin{array}{l}\text { Variables of } \\
\text { comorbidity }\end{array}$ & $\begin{array}{l}\text { Variables of } \\
\text { comorbidity }\end{array}$ & $\begin{array}{l}\text { Variables of } \\
\text { comorbidity }\end{array}$ & $\begin{array}{l}\text { Variables of } \\
\text { comorbidity }\end{array}$ & $\begin{array}{l}\text { Variables of } \\
\text { comorbidity }\end{array}$ \\
\hline $\begin{array}{l}\text { Arterial } \\
\text { hypertension } \\
{[\mathrm{n}(\%)]}\end{array}$ & $11228(83.6)$ & $23(0.2 \%)$ & $6525(85.2)$ & $4703(81.4)$ & $<0.001$ \\
\hline $\begin{array}{l}\text { Diabetes } \\
\text { mellitus [n } \\
(\%)]\end{array}$ & $5662(42.2)$ & $24(0.2 \%)$ & $3696(48.3)$ & $1966(34)$ & $<0.001$ \\
\hline $\begin{array}{l}\text { Dyslipemia [n } \\
(\%)]\end{array}$ & $5773(43)$ & $24(0.2 \%)$ & $3452(45.1)$ & $2321(40.2)$ & $<0.001$ \\
\hline $\begin{array}{l}\text { Ischemic heart } \\
\text { disease }[\mathrm{n}(\%)]\end{array}$ & $3933(29.3)$ & $25(0.2 \%)$ & $2474(32.3)$ & $1459(25.3)$ & $<0.001$ \\
\hline $\begin{array}{l}\text { Heart valve } \\
\text { disease }[\mathrm{n}(\%)]\end{array}$ & $3549(26.4)$ & $24(0.2 \%)$ & $2166(28.3)$ & $1383(23.9)$ & $<0.001$ \\
\hline $\begin{array}{l}\text { Atrial } \\
\text { fibrillation [n } \\
(\%)]\end{array}$ & $6560(48.8)$ & $24(0.2 \%)$ & $3766(49.2)$ & $2794(48.4)$ & 0.33 \\
\hline $\begin{array}{l}\text { Chronic } \\
\text { kidney disease } \\
{[\mathrm{n}(\%)]}\end{array}$ & $3390(25.2)$ & $22(0.2 \%)$ & $2479(32.4)$ & $911(15.8)$ & $<0.001$ \\
\hline $\begin{array}{l}\text { Cerebrovascular } \\
\text { disease }[\mathrm{n}(\%)]\end{array}$ & $1712(12.7)$ & $24(0.2 \%)$ & $1080(14.1)$ & $632(10.9)$ & $<0.001$ \\
\hline COPD [n (\%)] & $3229(24.1)$ & $31(0.2 \%)$ & $1942(25.4)$ & $1287(22.3)$ & $<0.001$ \\
\hline
\end{tabular}




\begin{tabular}{|c|c|c|c|c|c|}
\hline & $\begin{array}{l}\text { Total } \\
\mathrm{N}=13454\end{array}$ & Missing values & $\begin{array}{l}\text { ANEMIA } \\
\text { GROUP } \\
\mathrm{N}=7662\end{array}$ & $\begin{array}{l}\text { CONTROL } \\
\text { GROUP } \\
\mathrm{N}=5792\end{array}$ & p-value \\
\hline $\begin{array}{l}\text { Peripheral } \\
\text { artery disease } \\
{[\mathrm{n}(\%)]}\end{array}$ & $1205(9)$ & $26(0.2 \%)$ & $814(10.6)$ & $391(6.8)$ & $<0.001$ \\
\hline $\begin{array}{l}\text { Previous } \\
\text { episode of HF } \\
{[n(\%)]}\end{array}$ & $7973(60.3)$ & $222(1.7 \%)$ & $4854(64.3)$ & $3119(54.9)$ & $<0.001$ \\
\hline Basal status & & & & & \\
\hline $\begin{array}{l}\text { Basal NYHA } \\
\text { III-IV [n (\%)] }\end{array}$ & $3129(24.8)$ & $835(6.2 \%)$ & $1927(26.7)$ & $1202(22.2)$ & $<0.001$ \\
\hline $\begin{array}{l}\text { Barthel }<60 \\
\text { points }[\mathrm{n}(\%)]\end{array}$ & $2236(18.8)$ & $1542(11.5 \%)$ & $1406(20.7)$ & $830(16.3)$ & $<0.001$ \\
\hline $\begin{array}{l}\text { Treatment } \\
\text { prior to } \\
\text { emergency } \\
\text { department } \\
\text { care }\end{array}$ & $\begin{array}{l}\text { Treatment } \\
\text { prior to } \\
\text { emergency } \\
\text { department } \\
\text { care }\end{array}$ & $\begin{array}{l}\text { Treatment } \\
\text { prior to } \\
\text { emergency } \\
\text { department } \\
\text { care }\end{array}$ & $\begin{array}{l}\text { Treatment } \\
\text { prior to } \\
\text { emergency } \\
\text { department } \\
\text { care }\end{array}$ & $\begin{array}{l}\text { Treatment } \\
\text { prior to } \\
\text { emergency } \\
\text { department } \\
\text { care }\end{array}$ & $\begin{array}{l}\text { Treatment } \\
\text { prior to } \\
\text { emergency } \\
\text { department } \\
\text { care }\end{array}$ \\
\hline $\begin{array}{l}\text { Loop diuretics } \\
{[\mathrm{n}(\%)]}\end{array}$ & $8663(66.4)$ & $398(3 \%)$ & $5255(70.5)$ & 3408 (60.9) & $<0.001$ \\
\hline $\begin{array}{l}\text { Potassium } \\
\text { sparing } \\
\text { diuretics [n } \\
(\%)]\end{array}$ & $2239(17.2)$ & $400(3 \%)$ & $1338(17.9)$ & $901(16.1)$ & 0.005 \\
\hline $\begin{array}{l}\text { Thiazide } \\
\text { diuretics [n } \\
(\%)]\end{array}$ & $1836(14.1)$ & $401(3 \%)$ & $1024(13.7)$ & $812(14.2)$ & 0.22 \\
\hline $\begin{array}{l}\text { Beta- blockers } \\
{[\mathrm{n}(\%)]}\end{array}$ & $5283(40.5)$ & $404(3 \%)$ & 3081 (41.1) & $2202(39.3)$ & 0.019 \\
\hline $\begin{array}{l}\mathrm{ACE} \\
\text { inhibitors [n } \\
(\%)]\end{array}$ & $4380(33.6)$ & $400(3 \%)$ & $2495(33.5)$ & $1885(33.7)$ & 0.82 \\
\hline ARBs $[\mathrm{n}(\%)]$ & $3241(24.8)$ & $402(3 \%)$ & $1873(25.1)$ & $1368(24.4)$ & 0.35 \\
\hline $\begin{array}{l}\text { Oral anticoag- } \\
\text { ulation [n } \\
(\%)]\end{array}$ & $2551(19.5)$ & $401(3 \%)$ & $1490(20)$ & $1061(18.9)$ & 0.14 \\
\hline $\begin{array}{l}\text { Antiaggregants } \\
{[\mathrm{n}(\%)]}\end{array}$ & $4911(37.6)$ & $401(3 \%)$ & $2997(40.2)$ & $1914(34.2)$ & $<0.001$ \\
\hline $\begin{array}{l}\text { Digoxin [n } \\
(\%)]\end{array}$ & $2113(16.2)$ & $412(3.1 \%)$ & $1134(15.2)$ & $979(17.5)$ & 0.001 \\
\hline $\begin{array}{l}\text { Amiodarone }[\mathrm{n} \\
(\%)]\end{array}$ & $804(6.2)$ & $406(3 \%)$ & $307(5.5)$ & $497(6.7)$ & 0.005 \\
\hline $\begin{array}{l}\text { Nitrates }[\mathrm{n} \\
(\%)]\end{array}$ & 2349 (18) & $403(3 \%)$ & $1534(20.6)$ & $815(14.6)$ & $<0.001$ \\
\hline $\begin{array}{l}\text { Statins }[\mathrm{n}(\%)] \\
\text { Clinical data } \\
\text { of the acute } \\
\text { episode }\end{array}$ & $4584(42.1)$ & $2567(19.1 \%)$ & $2771(44.5)$ & $1813(38.9)$ & $<0.001$ \\
\hline
\end{tabular}




\begin{tabular}{|c|c|c|c|c|c|}
\hline & $\begin{array}{l}\text { Total } \\
\mathrm{N}=13454\end{array}$ & Missing values & $\begin{array}{l}\text { ANEMIA } \\
\text { GROUP } \\
\mathrm{N}=7662 \\
\end{array}$ & $\begin{array}{l}\text { CONTROL } \\
\text { GROUP } \\
\mathrm{N}=5792\end{array}$ & p-value \\
\hline $\begin{array}{l}\text { Heart rate }> \\
100 \mathrm{bpm} \\
{[\mathrm{n}(\%)]}\end{array}$ & $3314(25.3)$ & $335(2.5 \%)$ & $1575(21.1)$ & $1739(30.8)$ & $<0.001$ \\
\hline $\begin{array}{l}\text { Respiratory } \\
\text { rate > } 20 \mathrm{rpm} \\
{[\mathrm{n}(\%)]}\end{array}$ & $4597(49.4)$ & $4149(30.8 \%)$ & $2645(49.3)$ & $1952(49.6)$ & 0.76 \\
\hline $\begin{array}{l}\text { SBP }(\mathrm{mmHg}) \\
{[\text { mean (SD)] }}\end{array}$ & $141.3(27.9)$ & $226(1.7 \%)$ & $140.3(28,0)$ & $142.7(27.8)$ & $<0.001$ \\
\hline $\begin{array}{l}\mathrm{DBP}(\mathrm{mmHg}) \\
{[\text { mean }(\mathrm{SD})]}\end{array}$ & $76.3(17.5)$ & $237(1.8 \%)$ & $73.5(17.4)$ & $79.9(17.4)$ & $<0.001$ \\
\hline $\begin{array}{l}\mathrm{SatO} 2<90 \% \\
{[\mathrm{n}(\%)]}\end{array}$ & $2956(22.9)$ & $546(4.1 \%)$ & $1637(22.2)$ & $1319(23.8)$ & 0.03 \\
\hline $\begin{array}{l}\text { NYHA episode } \\
\text { III-IV [n (\%)] }\end{array}$ & $11553(89.1)$ & $493(3.7 \%)$ & $6666(90.1)$ & $4887(87.9)$ & $<0.001$ \\
\hline
\end{tabular}

SD: standard deviation; COPD: chronic obstructive pulmonary disease; NYHA: New York Heart Association; SBP: systolic blood pressure; DBP: diastolic blood pressure; ARBs: Angiotensin II receptor blockers; ACE: Angiotensin converting enzyme

Table 1 (cont.) Baseline characteristics of the study population and comparison of the characteristics of the patients based on whether they had anemia or not.

\begin{tabular}{|c|c|c|c|c|c|}
\hline & $\begin{array}{l}\text { Total } \\
N=13454\end{array}$ & Missing values & $\begin{array}{l}\text { ANEMIA } \\
\text { GROUP } \\
\mathrm{N}=7662\end{array}$ & $\begin{array}{l}\text { CONTROL } \\
\text { GROUP } \\
\text { N=5792 }\end{array}$ & p-valor \\
\hline $\begin{array}{l}\text { Laboratory } \\
\text { tests and } \\
\text { complemen- } \\
\text { tary } \\
\text { studies }\end{array}$ & $\begin{array}{l}\text { Laboratory } \\
\text { tests and } \\
\text { complemen- } \\
\text { tary } \\
\text { studies }\end{array}$ & $\begin{array}{l}\text { Laboratory } \\
\text { tests and } \\
\text { complemen- } \\
\text { tary } \\
\text { studies }\end{array}$ & $\begin{array}{l}\text { Laboratory } \\
\text { tests and } \\
\text { complemen- } \\
\text { tary } \\
\text { studies }\end{array}$ & $\begin{array}{l}\text { Laboratory } \\
\text { tests and } \\
\text { complemen- } \\
\text { tary } \\
\text { studies }\end{array}$ & $\begin{array}{l}\text { Laboratory } \\
\text { tests and } \\
\text { complemen- } \\
\text { tary } \\
\text { studies }\end{array}$ \\
\hline $\begin{array}{l}\text { Hemoglobin } \\
\text { (g/L) [mean } \\
\text { (SD)] }\end{array}$ & $11.98(2.09)$ & $0(0 \%)$ & $10.6(1.4)$ & $13.8(1.3)$ & $<0.001$ \\
\hline $\begin{array}{l}\text { Hematocrit } \\
(\%)[\text { mean } \\
(\mathrm{SD})]\end{array}$ & $37(6)$ & $253(1.9 \%)$ & $33(4)$ & $42(4)$ & $<0.001$ \\
\hline $\begin{array}{l}\text { EDW } \\
(\%)[\text { mean } \\
(\mathrm{SD})]\end{array}$ & $18(15)$ & $4347(32 \%)$ & $18.9(16.7)$ & $16.8(12.2)$ & $<0.001$ \\
\hline $\begin{array}{l}\mathrm{EDW}>16.5 \% \\
{[\mathrm{n}(\%)]}\end{array}$ & $3137(34.4)$ & $4347(32 \%)$ & $2261(43.2)$ & $876(22.6)$ & $<0.001$ \\
\hline $\begin{array}{l}\text { Leukocytes } \\
\text { (elements } \\
\text { /mm3) [media } \\
\text { (SD)] }\end{array}$ & $9427(6882)$ & $1531(11.4 \%)$ & $9271(7277)$ & 9611 (6297) & 0.007 \\
\hline
\end{tabular}




\begin{tabular}{|c|c|c|c|c|c|}
\hline & $\begin{array}{l}\text { Total } \\
\mathrm{N}=13454\end{array}$ & Missing values & $\begin{array}{l}\text { ANEMIA } \\
\text { GROUP } \\
\mathrm{N}=7662\end{array}$ & $\begin{array}{l}\text { CONTROL } \\
\text { GROUP } \\
\mathrm{N}=5792\end{array}$ & p-valor \\
\hline 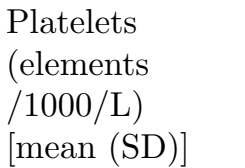 & $229.3(127.0)$ & $2296(17.1 \%)$ & $237(133)$ & 219 (119) & $<0.001$ \\
\hline $\begin{array}{l}\text { Mean platelet } \\
\text { volume (fl) } \\
{[\text { mean }(\mathrm{SD})]}\end{array}$ & $10.2(11.7)$ & $3835(28.5 \%)$ & $10.1(7.6)$ & $10.2(14.9)$ & 0.56 \\
\hline $\begin{array}{l}\text { Glucose } \\
(\mathrm{mg} / \mathrm{dl})[\text { mean } \\
(\mathrm{SD})]\end{array}$ & $149(84)$ & $1572(11.7)$ & $151(86)$ & $146(80)$ & 0.004 \\
\hline $\begin{array}{l}\text { Urea }(\mathrm{mg} / \mathrm{dl}) \\
{[\text { mean }(\mathrm{SD})]}\end{array}$ & $66.8(48.3)$ & $942(7 \%)$ & $73.8(52.2)$ & $57.3(40.2)$ & $<0.001$ \\
\hline $\begin{array}{l}\text { Cre atinine } \\
(\mathrm{mg} / \mathrm{dl})[\text { mean } \\
(\mathrm{SD})]\end{array}$ & $1.36(0.85)$ & $0(0 \%)$ & $1.50(0.96)$ & $1.16(0.61)$ & $<0.001$ \\
\hline $\begin{array}{l}\mathrm{eGFR}<60 \\
\mathrm{ml} / \mathrm{min} / 1.73 \\
\mathrm{~m} 2[\mathrm{n}(\%)]\end{array}$ & $8250(63.6)$ & $478(3.6 \%)$ & $5269(70.9)$ & $2981(53.8)$ & $<0.001$ \\
\hline $\begin{array}{l}\text { Sodium < } 135 \\
\mathrm{mEq} / \mathrm{l}[\mathrm{n}(\%)]\end{array}$ & $2437(18.5)$ & $284(2.1 \%)$ & $1523(20.3)$ & $914(16.1)$ & $<0.001$ \\
\hline $\begin{array}{l}\text { NTproBNP } \\
(\mathrm{mg} / \mathrm{dl})[\text { mean } \\
(\mathrm{SD})]\end{array}$ & $3918(55.1)$ & $7733(57.5 \%)$ & $8472(13676)$ & $6812(13093)$ & $<0.001$ \\
\hline $\begin{array}{l}\text { Positive } \\
\text { troponins [n } \\
(\%)]\end{array}$ & 7769 (13431) & $6349(47.2 \%)$ & $2296(58.4)$ & $1622(51.1)$ & $<0.001$ \\
\hline $\begin{array}{l}\text { Atrial } \\
\text { fibrillation in } \\
\text { the ECG } \\
{[\mathrm{n}(\%)]}\end{array}$ & $5918(48.6)$ & $1281(9.5 \%)$ & $3232(46.5)$ & $2685(51.4)$ & $<0.001$ \\
\hline $\begin{array}{l}\text { Emergency } \\
\text { department } \\
\text { treatment } \\
\text { and } \\
\text { management }\end{array}$ & $\begin{array}{l}\text { Emergency } \\
\text { department } \\
\text { treatment } \\
\text { and } \\
\text { management }\end{array}$ & $\begin{array}{l}\text { Emergency } \\
\text { department } \\
\text { treatment } \\
\text { and } \\
\text { management }\end{array}$ & $\begin{array}{l}\text { Emergency } \\
\text { department } \\
\text { treatment } \\
\text { and } \\
\text { management }\end{array}$ & $\begin{array}{l}\text { Emergency } \\
\text { department } \\
\text { treatment } \\
\text { and } \\
\text { management }\end{array}$ & $\begin{array}{l}\text { Emergency } \\
\text { department } \\
\text { treatment } \\
\text { and } \\
\text { management }\end{array}$ \\
\hline $\begin{array}{l}\text { Conventional } \\
\text { oxygen } \\
\text { therapy }[\mathrm{n}(\%)]\end{array}$ & $9767(73.4)$ & $145(1.1 \%)$ & $5647(74.5)$ & $4120(71.9)$ & 0.001 \\
\hline $\begin{array}{l}\text { Bolus of loop } \\
\text { diuretics } \\
{[\mathrm{n}(\%)]}\end{array}$ & $10762(80.9)$ & $143(1.1 \%)$ & $6187(81.6)$ & $4575(79.9)$ & 0.01 \\
\hline $\begin{array}{l}\text { Continuous } \\
\text { intravenous } \\
\text { perfusion of } \\
\text { loop diuretics } \\
{[\mathrm{n}(\%)]}\end{array}$ & $611(4.6)$ & $145(1.1 \%)$ & $353(4.7)$ & $258(4.5)$ & 0.68 \\
\hline $\begin{array}{l}\text { Intravenous } \\
\text { nitrates }[\mathrm{n}(\%)]\end{array}$ & $2064(15.5)$ & $143(1.1 \%)$ & $1195(15.8)$ & $869(15.2)$ & 0.35 \\
\hline
\end{tabular}




\begin{tabular}{|c|c|c|c|c|c|}
\hline & $\begin{array}{l}\text { Total } \\
\mathrm{N}=13454\end{array}$ & Missing values & $\begin{array}{l}\text { ANEMIA } \\
\text { GROUP } \\
\mathrm{N}=7662\end{array}$ & $\begin{array}{l}\text { CONTROL } \\
\text { GROUP } \\
\mathrm{N}=5792\end{array}$ & p-valor \\
\hline Digoxin $[\mathrm{n}(\%)]$ & $1881(14.1)$ & $144(1.1 \%)$ & $884(11.7)$ & 997 (17.4) & $<0.001$ \\
\hline $\begin{array}{l}\text { Morphine } \\
{[\mathrm{n}(\%)]}\end{array}$ & $681(6.1)$ & $2315(17.2 \%)$ & $382(6)$ & $299(6.2)$ & 0.62 \\
\hline $\begin{array}{l}\text { Stay in } \\
\text { Observation } \\
\text { Unit }[\mathrm{n}(\%)]\end{array}$ & $3810(30.3)$ & $883(5.6 \%)$ & $2252(31.3)$ & $1558(28.9)$ & 0.004 \\
\hline $\begin{array}{l}\text { Hospital } \\
\text { admission } \\
{[\mathrm{n}(\%)]}\end{array}$ & $10117(75.2)$ & $9(0.07 \%)$ & $5849(76.4)$ & $4268(73.7)$ & $<0.001$ \\
\hline Follow-up & Follow-up & Follow-up & Follow-up & Follow-up & Follow-up \\
\hline $\begin{array}{l}\text { In-hospital } \\
\text { mortality } \\
{[\mathrm{n}(\%)]}\end{array}$ & $1002(7.5)$ & $51(0.4 \%)^{*}$ & $648(8.5)^{2}$ & $354(6.1)^{2}$ & $<0.001$ \\
\hline $\begin{array}{l}\text { Mortality at } \\
30 \text { days }[\mathrm{n}(\%)]\end{array}$ & $1245(9.3)$ & $93(0.69 \%)$ & $816(10.7)$ & $429(7.5)$ & $<0.001$ \\
\hline $\begin{array}{l}\text { Mortality at } \\
180 \text { days } \\
{[\mathrm{n}(\%)]}\end{array}$ & $2755(20.6)$ & $93(0.69 \%)$ & $1791(23.5)$ & $964(16.8)$ & $<0.001$ \\
\hline $\begin{array}{l}\text { Mortality at } \\
\text { one year } \\
{[\mathrm{n}(\%)]}\end{array}$ & $3611(27)$ & $93(0.69 \%)$ & $2394(31.4)$ & $1217(21.2)$ & $<0.001$ \\
\hline $\begin{array}{l}\text { Reconsultation } \\
\text { to the ED [n } \\
(\%)]\end{array}$ & $4254(35.2)$ & $1694(12.3 \%)$ & $2574(37.8)$ & $1680(31.7)$ & $<0.001$ \\
\hline
\end{tabular}

SD: standard deviation; EDW: erythrocyte distribution width; ED: emergency department; eGFR: estimated glomerular filtration rate; NTproBNP: N terminal brain nutriuretic peptide; ECG: electrocardiogram;

\section{Hosted file}

Figura_1.docx available at https://authorea.com/users/342163/articles/469028-prognosticimplications-of-anemia-in-patients-with-acute-heart-failure-in-emergency-departmentsanem-ahf-study

\section{Hosted file}

Figura_2.docx available at https://authorea.com/users/342163/articles/469028-prognosticimplications-of-anemia-in-patients-with-acute-heart-failure-in-emergency-departmentsanem-ahf-study

\section{Hosted file}

Figure_3.docx available at https://authorea.com/users/342163/articles/469028-prognosticimplications-of-anemia-in-patients-with-acute-heart-failure-in-emergency-departmentsanem-ahf-study

\section{Hosted file}

Figure_4.docx available at https://authorea.com/users/342163/articles/469028-prognosticimplications-of-anemia-in-patients-with-acute-heart-failure-in-emergency-departmentsanem-ahf-study 


\section{Hosted file}

Figure_5.docx available at https://authorea.com/users/342163/articles/469028-prognosticimplications-of-anemia-in-patients-with-acute-heart-failure-in-emergency-departmentsanem-ahf-study 